\title{
René Guénon and Traditionalism
}

\author{
William Rory Dickson
}

\section{1 \\ Introduction}

René Guénon's (1886-1951) Traditionalist school of thought has played a significant role in the transmission of Islam within Europe and North America. Like Guénon, most of his followers became Muslim and pursued the practice of Șūfism within several Traditionalist Șūfi orders, making Traditionalism a largely Islamic movement. Several of Guénon's followers were accomplished academics whose writings on Islam have shaped its reception in the West more broadly, particularly among intellectuals and Șūfis. This chapter will first of all outline Guénon's life and thought, before considering the broader Traditionalist movement and its role in the development of Islam in the West in the twentieth century.

Initiated into a Șūfi order in 1910, Guénon sought to recover humanity's 'Primordial Tradition' (la Tradition Primordiale), whose metaphysical truths he believed were still preserved within Eastern religions. Although Guénon held that Hinduism's non-dual Advaita Vedanta school was the most authoritative expression of the Primordial Tradition, he did not think Hinduism suitable for Westerners, and saw in Islam a more recent and accessible expression of the Primordial Tradition. Guénon's emphasis on orthodox religion as the necessary container of esoteric truth, alongside his trenchant critique of modernity, led to his school of thought being referred to as Traditionalism.

His initiation into Șūfism, and later devout practice of Islam, would prove to have historical significance for Islam in the West, as several of his followers and associates would become Muslims, establish their own branches of Șūfi orders in Europe and North America, and further write influential interpretations of Islam for Westerners. Most notably Frithjof Schuon (1907-1998) would publish numerous books expanding upon Guénon's thought and initiate several European and North American intellectuals into his Șūfi order, the Maryamiyya. Together, Schuon and Guénon's writings would form the core works of the Traditionalist school of thought. Traditionalism has been particularly influential among Western scholars of Islam, including Titus Burckhardt (1908-1984), Michel Chodkiewicz (b. 1929), Martin Lings (1909-2005), and Seyyed Hossein Nasr (b. 1933), many of whose students have become established scholars in 
their own right. The many works by Traditionalist scholars published in the last century have helped shape Western discourse on Islam more broadly, but especially in regards to Șūfism.

René-Jean-Marie-Joseph Guénon was born in Blois, France in 1886, to a bourgeois Catholic family. Despite a delicate constitution and recurrent health issues he excelled as a student, obtaining baccalaureates in philosophy and mathematics (Borella 1992: 330). In 1904 he began a mathematics program at the Collège Rollin in Paris, hoping to eventually enter the prestigious École Polytechnique. Guénon struggled with his studies, however, and withdrew from college in 1906, leaving the Latin Quarter for the more placid Ile Saint-Louis. His interests were increasingly drawn towards the thriving occult scene offered by fin de siècle Paris, a scene he would immerse himself in over the next six years.

Guénon's occult pursuits were mediated through Gérard Encausse (18651916) or Papus as he was also known. A physician interested in alternative medicine, Encausse became a pillar of Paris's occult milieu. He established several esoteric organisations that Guénon would become affiliated with, including the École Hermétique and Ordre Martiniste. Encausse's interests overlapped with Theosophy, and he had been a member of the Paris branch of the Theosophical Society since 1887. Emerging out of nineteenth century Spiritualism, Theosophy offered a synthesis of Western and Eastern esoteric traditions. Established in 1875 in New York, by 1890 the Theosophical Society had over 200 branches, with publishing houses in America, Britain, France, India, and Sweden (Dickson 2015: 68).

For Theosophy's founders, Henry Steel Olcott (1832-1907) and Helena Petrovna Blavatsky (1831-1891), a unitary truth lay at the core of the various religions and philosophies of human history, perennially present though expressed in different forms. Their perennialism was based on the prisca theologica of the Renaissance, an idea that can be traced to the Council of Ferrera (1438-1439) in Florence, Italy. Here, Georgios Gemistos Plethon (1355-1452), a Neoplatonist scholar of the Byzantine delegation, suggested to Catholic Florentines that a deep understanding of Plato could lead to the harmonisation of divergent philosophical and religious views, with outward differences resolved in a transcendent unity. Plethon drew Cosimo de' Medici's (1389-1464) attention. A wealthy Florentine noble, de' Medici would become a patron of Neoplatonic and Hermetic thought during the Renaissance, funding Marsilio 
Ficino's (1433-1499) revived Platonic Academy. Ficino was an influential proponent of the prisca theologica, arguing that all true religion and philosophy were diverse manifestations of a single truth, just as all visible forms shared a deeper ontological unity. The phrase philosophia perennis itself was later coined by the Italian humanist Agostino Steuco (1497-1548), who built upon Ficino's perennialism in his De perenni philosophia (1540) (Schmitt 1966: 505-506).

Perennialism found renewed cachet during the eighteenth and nineteenth centuries, as Europeans began to encounter non-Western languages, philosophies, and religions in much greater depth, with the access afforded by Western imperial and colonial expansion. Exemplary here is the founding father of British Orientalism, Sir William Jones (1746-1794), an accomplished philologist, translator, and jurist, who was appointed as a judge in the British supreme court in India in $1783 .{ }^{1}$ In his study of Hindu and Șūfi philosophy, Jones saw shared patterns with Plato in the West, all of which he believed to be derived from an ancient, primordial "metaphysical theology" (Dickson 2015: 37). Jones's version of the prisca theologica included the Vedanta (Hinduism's most influential philosophical school) ${ }^{2}$ as particularly profound representative of the Primordial Tradition. According to Jones, "It is impossible to read the Vedanta, or the many fine compositions in illustration of it, without believing that Pythagoras and Plato derived their sublime theories from the same fountain with the sages of India" (Benoit 2010: 92).

Jones is further credited with discovering the Indo-European language family. In his famous address to the Asiatic Society of Bengal in 1786, he outlined the connections between Sanskrit, Persian, Latin, and Greek. This Indo-European or 'Aryan' language family would be increasingly conceived of in racial terms in the century that followed, with an imagined superiority over its Semitic counterpart (Masuzawa 2005: 150-151). As Gregory A. Lipton observes, "The idea of the metaphysical superiority of the so-called Aryan spirit in relation to Hinduism - or more esoterically conceived as 'the Vedanta'-formed a large part of the Romantic fascination with India" (Lipton 2018: 128). This

1 Jones played a paramount role in introducing Westerners to "Oriental" philosophies and religions, creating the first society and journal devoted to the study of the Orient in 1784. For more on his life and work, see Franklin (2011).

2 Vedanta is considered to be one of six Darshanas or philosophical schools within Hinduism, that had largely crystalised by the twelfth century. It has developed through commentaries on the Upanishads, Bhagavad Gita, and on the Vedanta-Sutras (Doniger 2009: 505). Orientalist understandings of Vedanta were largely based upon Shankara's (c. 788-820) Advaita (nondual) school, which asserted that the self (atman) or subjectivity is ontologically identical with the absolute (brahman), and that spiritual liberation (moksha) is attained through knowledge of this identity. 
Vedanta-oriented perennialism, in part based upon a notion of Aryan philosophical superiority, would be further elaborated upon by Theosophists in the nineteenth century and Traditionalists in the twentieth.

In her major works Isis Unveiled (1877) and The Secret Doctrine (1888), Blavatsky suggested that the "Secret Doctrine" was an ancient system of esoteric knowledge, synthesising both the truths of religion and science, with the potential of uniting people across boundaries of religion, race, and culture. This perennial wisdom was best preserved in the East with Vedanta and in the West with the Hermetic texts. Despite sharing this version of perennialism with Theosophists, Encausse was drawn to Masonic rites, something most Theosophists were not. In 189 o he founded the Ordre Martiniste as a sort of neo-Masonic movement, with a focus on esoteric symbolism and initiation. Perceiving a threat to her authority, Blavatsky published critiques of Encausse in her new journal La Revue Théosophique. In response Encausse established his own journal, Le Voile d'Isis, publishing articles critical of Blavatsky and Theosophy (Sedgwick 2004: 46-47).

Alongside a Vedanta-oriented perennialism, ${ }^{3}$ Guénon would inherit Encausse's concern with symbolism and initiation, as well as his disdain for Theosophy. However, Guénon's quest for an authentic initiatory tradition would also draw him away from Encausse. During a séance in 1908, Guénon believed that Jacques de Molay (1243-1314), the Knights Templar's last Grand Master, contacted him with instructions to re-establish the Order of the Temple, providing him with a direct source of initiation (Sedgwick 2004: 49). Several Martinists joined Guénon's Ordre du Temple Renové. Encausse saw this as a threat and consequently expelled Guénon from his order. Guénon's search for spiritual authenticity would continue.

In 1909 he joined the Église Gnostique, established by Jules Benoit Doinel (1842-1903) in 1888. After joining, Guénon established La Gnose, a journal affiliated with the church. The Gnostic Church is where Guénon would meet Count Albert de Pouvourville (1861-1939), a French solider, writer, and journalist who claimed to receive a 'Taoist initiation' from Vietnamese Triads after his desertion from the French military in Vietnam. Guénon would credit de Pouvourville as his source for the idea that the Primordial Tradition is one, and, with a dig at the Catholic Church, that "parasitic vegetation must not be

3 Harry Oldmeadow summarises the centrality of perennialism to Guénon's thought as follows: "The existence of a Primordial Tradition embodying a set of immutable metaphysical and cosmological principles from which derive a succession of traditions each expressing these principles in forms determined by a given Revelation and by the exigencies of the particular situation, is axiomatic in Guénon's work" (Oldmeadow 1995: 5). 
confused with the very Tree of Tradition" (Sedgwick 2004: 57-58). Although Guénon later hoped to recover access to the Primordial Tradition within Catholicism, he would eventually conclude that the Church had been too tainted by the modern spirit, and that authentic initiations into the Primordial Tradition could only be found in the East.

His Gnostic affiliation would further lead him to Ivan Aguéli (1869-1917), who would ultimately have a pivotal influence on Guénon's life and path. Aguéli was a Swedish-born convert to Islam, Șūfi, and artist, who also joined the Gnostic Church and began writing articles on Șūfism for La Gnose. Also known as Shaykh 'Abd al-Hādī al-'Aqīlī, Aguéli was a representative (muqaddam) of Shaykh 'Abd al-Rahman 'Illaysh (1845-1921), leader of the Shadhiliyya 'Arabiyya Șüfi order in Cairo. Through Aguéli, Guénon was initiated into the Shadhiliyya 'Arabiyya in 1910, and began to correspond with 'Illaysh, becoming a Muslim and taking the name 'Abd al-Wahid Yahya. Guénon soon dissolved his Ordre du Temple, though there is little evidence to suggest that he adopted the practice of Islam until decades later, despite his perhaps perfunctory conversion.

It is important to note here that, while living in Damascus, 'Illaysh had been an associate of the famous Algerian philosopher, Șūfi, and military leader, amìr 'Abd al-Qādir al-Jazāirī (1808-1883). Like al-Jazāirī, 'Illaysh was a proponent of the thought of the medieval Șüfi philosopher Muhyī al-Dīn Ibn al-'Arabī (1165-1240) (Chodkiewicz 1995). Traced from al-Jazā'irī, through 'Illaysh, and then from Aguéli to Guénon, the thought of Ibn al-Arabī would come to have a prominent role in Traditionalist circles, being seen as something like a Muslim equivalent to Hindu Vedanta. This embrace of Ibn al-'Arabỉ's school of thought was not merely coincidental however. Considered by many Șüis to be the shaykh al-akbar or 'greatest master' of the Șūfi tradition, as well as the most influential expounder of the 'oneness of being' (wahdat al-wujūd), ${ }^{4}$ Ibn al-'Arabi's non-dual philosophy was another example for Traditionalists of what they took to be the core doctrine of the Primordial Tradition: the inherent oneness or non-duality of existence.

During this period Guénon began to believe that the ancient wisdom of the Primordial Tradition could only be authentically found within orthodox religious forms, something that would distinguish his perennialism from that of Martinists and Theosophists. This turn towards tradition would coincide with

4 Although Ibn al-'Arabī and his students certainly held that wujüd or 'being' is one, the use of the term wahdat al-wujüd in a polemical context frequently led to misunderstandings of the term. Hence, its appropriateness as an accurate representative of Ibn al-Arabi's school of thought remains a subject of debate. For more see Chittick (2004). 
his marriage to a devout Catholic woman, Berthe Loury (d. 1927) in 1912. In 1915 Guénon began attending lectures at the Institut Catholique, where his emerging orientation towards tradition fit well with the Institute's conservative Catholicism. Guénon's experience of Paris's occult underground convinced him that authentic initiation was not to be found there, and his increasingly critical view of Spiritualist and Theosophical groups was lauded by many in Catholic circles (Dickson 2015: 71).

Despite his initiation into Șūfism, and mutual sympathy with traditionoriented Catholics, Guénon considered Hinduism's Vedanta to be the most explicit articulation of the Primordial Tradition. This did not mean that he understood Vedanta to have a categorical superiority over other traditions, but merely that he thought it offered the most incisive expression of the truths shared by them all. Regarding this essential unity of traditions, Guénon writes:

The real traditional outlook is always and everywhere essentially the same, whatever outward form it may take; the various forms that are specially suited to different mental conditions and different circumstances of time and place are merely expressions of one and the same truth; but this fundamental unity beneath apparent multiplicity can be grasped only by those who are able to take up a point of view that is truly intellectual.

GUÉNON 2004 [1927]: 30

By "intellectual," Guénon here means a point of view based on objective intellection, or pure gnosis, which he considers to be of a "supra-individual order," in contrast with the inherently individual, subjective nature of rational human thought (2004 [1945]: 90). Schuon would consider this to be one of the great contributions of Guénonian thought, "to have recalled what modern thought ... has forgotten or sought to forget, namely the essential distinction between intellectual intuition and mental operation, or, in other words, between the Intellect, which is universal, and the reason, which is individual" (Schuon 2004 [1984]:1).

Guénon wrote a dissertation on Vedanta in 1920 that was rejected by French Indologist Sylvain Levi (1863-1935). Levi discounted Guénon's assertion of a perennial tradition traced back to earliest humanity, and further disagreed with situating Vedanta as representative of Hinduism more broadly (Sedgwick 2004: 22-23). The French Catholic philosopher Jacques Maritain (1882-1973) liked the book however, and recommended it for publication. It would become Guénon's first book, L'introdution générale à l'étude des doctrines hindoues, published in 1921. That same year he also published a series of polemical articles in the Institut Catholique's journal Revue de philosophie, denouncing Theosophy 
as a "pseudo-religion." In a similar vein, he published L'erreur spirite in 1923 as a refutation of the errors of modern Spiritualism. Guénon's critique of Theosophy and Spiritualism was informed by his growing concern to distinguish authentic forms of initiation from inauthentic ones, which he termed "counter-initiation."

His concern to exclude heretical traditions could be taken too far even for some of his Traditionalist associates. For example, Guénon initially believed that Buddhism was not an inherently orthodox expression of the Primordial Tradition, but rather a heretical deviation from Hinduism. It was only after extensive correspondence with fellow Traditionalists Marco Pallis (1895-1989), who himself was a practitioner of and writer on Tibetan Buddhism, Ananda K. Coomaraswamy (1877-1947), a Tamil philosopher with a far deeper understanding of Buddhism, and Schuon, who had also read more extensively on Buddhism, that Guénon would eventually revise his opinion and consider it an authentic tradition (Waterfield 2002: 47; Fitzgerald 2010: 54).

Guénon's persistent interest in 'Oriental metaphysics' eventually dried up his support in Catholic circles, including that of Maritain. In his fourth work, Orient et Occident (1924), Guénon proposed that the forthcoming collapse of Western civilisation could only be averted with the help of Eastern traditions. For Guénon, the modern world was starkly contrasted with its Eastern predecessors: Western modernity was a materialistic deviation from the traditional norm, as represented by the classical civilisations, of India, China, and the Middle East. In his La crise du monde moderne (1927), he suggested that, "Easterners are justified in reproaching modern Western civilisation for being exclusively material," as Western materialism is "a complete state of mind ... one that consists in more or less consciously putting material things, and the preoccupations arising out of them, in the first place" (Guénon 2004 [1927]: 81-82). Less geographical entities, for Guénon the 'West' and the 'East' were first and foremost mentalities, one grounded in tradition, the other deviating from it.

In contrast to the modern West, Eastern civilisations were exemplary as their art, law, religion (and most importantly esoteric teachings), preserved the sacred, metaphysical knowledge of the Primordial Tradition. As a result, the East maintained contact with divine truth, and hence experienced a civilisational balance and health as a result. Although the modern West appeared

5 On the Theosophical appropriation of Hindu terminology, Guénon suggests "the self-styled Theosophists ... are almost completely ignorant of Hindu doctrines, and have derived nothing from them but a terminology which they use entirely at random" (Guénon 2001 [1925]: 18). 
to offer moral, scientific, and technological progress, this appearance was an inversion of the stark reality: modernity represented a movement away from traditional principles, and even a diabolical inversion of traditional truths, leading to the atrophying of genuine knowledge, social fragmentation, conflict, and the eventual dissolution of human civilisation (Dickson 2015: 71).

Guénon critiqued "the profane sciences of which the modern world is so proud" as "really and truly only the degenerate 'residues' of the ancient traditional sciences," just as "quantity itself, to which they strive to reduce everything" is "no more than the 'residue' of an existence emptied of everything that constituted its essence" (Guénon 2004 [1945]: 5). In general, he described the conditions of the contemporary period as those of the Kali Yuga or Dark Age of the Hindu cosmic cycle. Elaborating upon this notion, Guénon suggested that over time, cosmic manifestation moved further from its metaphysical source and unified principle (Brahman) thereby experiencing greater materialism, quantification, fragmentation, and spiritual-moral decline. As Mark Sedgwick notes, Guénon's perennialism is distinguished from its Theosophical counterpart with this pessimistic understanding of the modern world (Sedgwick 2004: $50-51)$.

In the 1920s, Guénon seemed to find a certain equilibrium. He was working as a schoolteacher, married and raising his niece, with his Traditionalism gaining ground as a respectable philosophy. His life would take a quite different turn beginning in 1927, however, when his wife died during an operation, his niece was taken from his care, and he lost his job as a teacher. By this time, he had also soured on the possibility of finding a convivial home for his Traditionalism within the Catholic Church. In 1930 Guénon traveled to Egypt in the hopes of finding Șūfi texts for translation and publication (Borella 1992: 334). Although initially struggling to get by, alone and penniless in Cairo, he increasingly integrated into Cairo life, and eventually decided against returning to France. In 1934 he married Fatima Muhammad Ibrahim, a devout Muslim Egyptian woman, with whom he would have four children.

In marked contrast to many urban Egyptians, who were adopting Western clothing, Guénon wore the traditional jalabiyya, and maintained the life of a committed Muslim: praying, fasting, and following the dictates of the sharía in his personal life. He also joined the Hamdiyya branch of the Shadhili order, as 'Illaysh's 'Arabiyya had largely dissolved (Sedgwick 2004: 75-76). Guénon maintained some link to traditional Egyptian elites through Shaykh 'Abd al-Ḥalīm Mahmūd (1910-1978), an accomplished scholar of law and Șūism, who would later become the head of al-Azhar Mosque. Maḥmūd wrote a book about Guénon in 1954, al-Faylasuf al-Muslim: René Guénon 'Abd al-Wahid 
Yahya, in which honorifically referred to him as an 'arif bi-llah or 'knower of God' (Laude 2010: 9). Guénon's wholesale embrace of life in Egypt is in part indicated by his formally becoming an Egyptian citizen in 1949 (Borella 1992: 334).

During his years in Egypt Guénon's sense of the importance of having an orthodox religious form within which to practice the esoteric path crystalised. He would eventually conclude that authentic initiation is always an integral part of a complete religious tradition, with its doctrines, rituals and rules all collectively forming a living, organic whole. To isolate one aspect of a religious tradition from others, or to mix elements of different traditions, was to destroy this organic coherence and the providential power it transmitted. This was precisely what he accused Theosophy of, and why he considered it to be a counter-initiatory tradition. In his Initiation et réalisation spirituelle (1952), Guénon concisely articulates the Traditionalist position on the necessity of following a particular religious form: "Whoever makes himself out to be a spiritual teacher without attaching himself to a specific traditional form, or without conforming to the rules established by the latter, cannot truly possess the qualifications he appropriates to himself" (Guénon 2004 [1952]: 110). Very much in line with classical Muslim understandings of Șūfism, that suggested the spiritual path (tariqa) could only legitimately occur within the confines of Islamic law and ritual life (sharīa), Guénon held that authentic Șūism always coincided with a devout Muslim life.

Despite living a life that, to all outward appearances, indicated a deep conversion to Islam, Guénon did not consider himself to have converted. He was careful to specify that his practice of Islam did not imply "the attribution of the superiority of one traditional form over another," but was rather a question of "spiritual expediency," as an understanding of "the essential unity of all traditions" rendered the possibility of conversion "meaningless and truly inconceivable" (Guénon 2004 [1952]: 63). Schuon notes that at the time of his embrace of Islam, Guénon did not believe that Buddhism was an authentic tradition, nor did he think that Christianity retained any genuine esotericism. Further, believing that an orthodox Hindu need be born into the caste system, Islam appeared to be his only option to access the Primordial Tradition through an initiatory esotericism within an orthodox religion (Schuon 2004 [1984]: 6). Although a committed Muslim in practice, Guénon continued to use Hindu terminology in his metaphysical expositions, with the belief that "Hinduism serves as the standard and central tradition for present humanity" (Borella 1992: 332). However, for the reasons mentioned above, Guénon did not see the practice of Hinduism as a viable way for Westerners, and instead saw 
in Islam the most recent and final manifestation of the Primordial Tradition in this cosmic cycle, one particularly suitable for moderns looking to recover universal truths in a traditional context.

This synthesis of primarily Vedanta-based expositions of metaphysics with Islamic path and practice would leave a lasting imprint on Traditionalism. Indeed, Guénon published seventeen works during his life, with eight volumes produced following his death, collectively constituting the doctrinal base for Traditionalism. Harry Oldmeadow concisely summarises Guenon's writings, noting that they cover "a vast terrain-Vedanta, the Chinese tradition, Christianity, Șufism, folklore and mythology form all over the world, the secret traditions of gnosticism, alchemy, the Kabbalah," regardless of subject however, "always intent on excavating their underlying principles and showing them to be formal manifestations of one Primordial Tradition" (Oldmeadow 1995: 275). The main themes of Guénon's body of work include: 1) a concern with articulating a universal metaphysics underlying diverse religious expressions, or perennialism; 2) defining the relationship between the esoteric and exoteric aspects of tradition; 3 ) analyzing various religious symbols, drawing out their universal implications, and; 4) a trenchant critique of inauthentic forms of initiation, and of the modern world more broadly (Laude 2010: 14). These themes would continue to shape Traditionalism following Guénon's death, largely under the leadership of Frithjof Schuon (1907-1998).

\section{Guénon's Influence and Successors}

As a result of his extensive writings and correspondence, Guénon would have significant influence, and yet until recently there was little academic attention paid to him. In the 1980s Joyce O. Lowrie observed that, “despite Guénon's having written twenty-six books and hundreds of articles in his lifetime, and despite the fact that at least seven books have been written about him, he is still virtually unknown" (1985: 392). Sedgwick suggests Guénon's absence from academic discussion is rooted in the general scholarly skepticism and even hostility towards writings based on esoteric principles, and further resulting from Guénon's unique style of French writing, which includes his own terminology developed independently of contemporary academic approaches (Sedgwick 2008: xvii-xviii).

Recently however, Wael Hallaq, scholar of Islamic law and intellectual history, has argued in Restating Orientalism: A Critique of Modern Knowledge (2018) that Guénon's deep critique of modernity "is gaining enough appeal that it has become recently relevant for many intellectual concerns," including 
postcolonial studies and environmental ethics (2018: 144). Hallaq suggests that Guénon offers a more thorough and effective critique of Western modernity than Edward Said (1935-2003) does in Orientalism (1978), arguing that "Guénon begins where Said ends" (2018: 145). Besides noting that Guénon was not discussed by Said, and in fact complicates Said's concept of Orientalism, Hallaq valorises Guénon as being 'ahead of his time' with a prescient diagnosis of Western modernity's destructive deviation from traditional metaphysics, social norms, and structures. He suggests that Guénon's work "captures much of the best in recent social theory, Critical Theory, and cultural criticism, but without admitting the legitimacy of the system on which these critical theories insist" (2018: 145). As Sedgwick notes, Hallaq's "use of Guénon represents a Traditionalist breakthrough into the Western intellectual mainstream" (Sedgwick 2019).

Despite his (until quite recently) marginal presence in mainstream academic discourse, Guénon was critically important for the development of Sunfism in the West. Though Guénon never recommended in print that his readers convert to Islam or practice Șufism, "most of those who were influenced by him did become Sufis" (Rawlinson 1997: 280). Hence the majority of Guénon's intellectual heirs followed Guénon's own example of becoming Muslim and were likely influenced by his understanding of Islam as the final manifestation of the primordial tradition in this cosmic cycle.

The spread of Traditionalism and Traditionalist Șūfism in the later twentieth century however was largely the result of the writings and teachings of Guénon's successor of sorts, Frithjof Schuon (1907-1998) or Shaykh 'Isa Nur al-Din, as his followers referred to him. Schuon's father was a concert violinist, and perhaps growing up with a musician had some influence on Schuon's later emphases on aesthetics and beauty, as well as his own poetry and painting. Schuon grew up a Lutheran, but at his father's request converted to Catholicism at the age of fourteen. During his school years he became friends with Titus Burckhardt, who would become a prominent Traditionalist author in his own right (see, for example, Burckhardt 1992, 2008, 2010).

After his father's death, while he was still a teenager, Schuon became a textiledesigner to support himself. He was also an avid reader of books on religion and philosophy, and became particularly entranced with Hinduism (Fitzgerald 2010: 13). When he was sixteen, Schuon read Guénon's Orient et Occident, and was profoundly affected. As a result he corresponded with Guénon, who, in 1931, advised him to look to Islam and Ṣufism. Although he was an avid student of Advaita Vedanta, Schuon agreed with Guénon that it was not a valid path to spiritual realisation for Europeans, as one could not technically convert to Hinduism. So, despite some reservations, in 1932 Schuon spent four months at 
the 'Alawi Şüfi center in Mostaganem, Algeria, under the tutelage of the famous Shadhili master Ahmad al-'Alawi (1869-1934), where he would embrace Islam and enter the Sunfi path. He returned to Europe and established a branch of the 'Alawiyya, with mostly fellow Guénonians joining. Burckhardt was impressed with Schuon's change and wanted to go to Mostaganem himself. However, with al-'Alawi's health in decline, Burckhardt decided to pursue Șūfism in Fez, Morocco, where he would study Arabic, convert to Islam and become a member of the Darqawi Șüfi order. Despite his own extensive initiatory experience with Șūfism, Burckhardt continued to acknowledge Schuon as the leader of their burgeoning Șūfi circle (Sedgwick 2004: 87).

In 1934 Schuon described mystically receiving the highest 'Alawi spiritual practice, the use of the Supreme Name in recitation (Allah), while reading the Bhagavad Gita in Paris (Sedgwick 2004: 88). In 1935 Schuon returned to Mostaganem where he was authorised as a representative (muqaddam) of the 'Alawi order. This authorisation has led to some debate as the Arabic certificate he was given appears to authorise Schuon as one who can call people to the Islamic faith, without specifying any initiatory authority beyond that. But for his followers, this authorisation was taken to include a broader spiritual authority. Regardless, in 1937 Schuon experienced a vision that he believed authorised him as a Șüfi master (shaykh) in his own right, and dreams reported by his followers were taken as confirmation. Guénon would continue to send interested seekers to Schuon, and his order would grow during the 193os until, at the end of the decade, he had established centers in Paris, Amiens, and Basel (Sedgwick 2017).

Notable for his later influence as a scholar of Islam, Martin Lings would join the 'Alawiyya in 1938 after reading Guénon. He became an associate of Guenon's while teaching in Cairo during the Second World War (Sedgwick 2004: 119). Lings is perhaps most broadly known for his highly-regarded English version of the Prophet Muhammad's biography (Lings 2006). Lings would later go on to establish himself as a respected scholar and member of Britain's Muslim community. His A Sufi Saint of the Twentieth Century: Shaykh Ahmad al-Alawi (1993) remains a popular study of al-'Alawi and Șūfism more broadly. Lings also quietly led Maryamiyya circles in Jordan and the United Kingdom, both connected to the royal families of those countries, with Prince El Hassan Bin Talal and Prince Charles both having notable interest in Traditionalism, and personal connections with Lings (Sedgwick 2011: 177).

Schuon maintained the style of $d h i k r$ (remembrance of God, usually chanting) practiced by the 'Alawiyya. He taught his students salat (the five daily prayers), and suggested they follow the basic moral and ritual guidelines provided by the sharita. However, in contrast to broader 'Alawi practice, Schuon 
emphasised the primacy of the dhikr practice, downplaying other devotional forms usually associated with Șüfi practice. This was part and parcel of Schuon's concern to avoid the limitations of "average Sufism," which for Schuon was based on a simplistic pietism and sentimentality that failed to produce genuine spiritual realisation or gnosis.

Distinguishing his own path from what he saw as the limitations of conventional Șūfism, Schuon noted that, "our point of departure is the Advaita Vedanta and not a moralist, individualist and voluntarist anthropology with which ordinary Sufism is undeniably identified" (Sedgwick 2004: 170). Like Guénon, Schuon held that Vedanta "stands out as one of the most direct formulations possible of what constitutes the very essence of our spiritual reality" (Schuon 2003 [1959]: 19). Although for Schuon the "Vedantic perspective finds its equivalents in the great religions which regulate humanity," non-Vedantic formulations "may be dependent on dogmatic perspectives which restrict their immediate intelligibility," making them less accessible (Schuon 2003 [1959]: 19). Hence for Schuon, Vedanta was something like a key unlocking the very same truths found at the heart of Șufism, truths only obscured by the limitations of Islamic theology. On this point he elaborated, "we take our stand on Shankaracharya [the founder of Advaita Vedanta], not on an Ibn 'Arabī; the latter we accept only insofar as we find in him something of the Vedanta" (Lipton 2018: 138). To the extent that Traditionalists have embraced Ibn al-'Arabī, some of their interpretations have been critiqued for downplaying "exclusivist notions of religious supersessionism and [Islamic] socio-politcal authority" in Ibn al-Arabì's thought, in effect reframing his work along the lines of Tradtionalist perennialism (Lipton 2018: 9).

In line with nineteenth cenutry Orientalist and German Romanticist understandings of language family and race, Schuon believed that Șüfism suffered from a Semitic "subjectivism," and hence it lacked the objectivity to "consistently discern the transcendent formlessness of essential truth from religious particularism," while holding that the "Aryan metaphysics of Vedanta and Platonism" retained this objectivity (Lipton 2018: 122). In his work Le Soufisme: voile et quintessence (1980) Schuon summarises his perspective on this issue describing Aryans (Indians, Persians, and Europeans) as "above all metaphysicians and therfore logicians," while characterising Semites (Jews and Arabs) as "a priori mystics and moralists," and "subjectivists" (Schuon 2006 [1980]: 21). ${ }^{6}$

6 Although the concepts of "Aryan" and "Semitic" are integral to Schuon's analysis of various traditions, he limits their importance in affirming that, "it is only too obvious that the great question that arises for man is not to know whether he is Semitic or Aryan, Oriental or Western, but to know whether he loves God" (Schuon 2006 [1980]: 26). 
In contrast to Schuon's self-described Aryanism, Guénon dismissed the notion of the 'Aryan race' as an Orientalist fiction devoid of substance (Lipton 2018: 243).

Schuon's streamlining of devotional practice combined with a doctrinal focus on Vedanta clearly set his Șüfism apart from the phenomenon as it tended to function in Muslim-majority contexts, though his Șüfism still remained largely within the parameters of Guénon's thought. The coming decades however would see Schuon take his thought and his Süfi order in directions disapproved of by Guénon. Notably, Schuon's thought diverged from Guenon's in terms of Christianity and the West. Whereas Guénon eventually concluded that authentic inititation could no longer be found within the Catholic Church, and that the West was largely devoid of genuine traditional knowledge, Schuon believed that not only Catholicism but also the Lutheranism of his youth retained some esoteric efficacy, and that the West still maintained some elements of traditional doctrine. On this, Schuon wrote, "Guénon is magisterial in his defense of the traditional East and his condmenation of the anti-traditional West, but he overestimates Eastern man as such and underestimates Western man as such" (Schuon 2004 [1984]: 20).

Further, whereas Guénon emphasised the incontrivertible necessity of adhering to an exoteric form if the integrity of esoteric truth was to be maintained, Schuon leaned more towards embracing a universal metaphysics that transcended religious forms. Schuon went so far as to suggest that religions are like heresies in comparison to the perennial philosophy on which they are based. Thus Schuon relaxed or simplified the obligations of Islam for his followers, including permission for some not to fast during Ramadan, and the allowance of practicing the prayers at irregular times to avoid difficulties. He further allowed his students to drink alcohol with European family and friends, so as not to create social controversy. On the primacy of the perennial or universal truth over religious form, Schuon wrote, "the goal of the work is not the Islamic form as such, but precisely esoterism as such ... This is Islam, not as the daily universe of Arab sentiments and passions, but as the manifestation at the end of time of the primordial religion" (Fitzgerald 2010:40).

This concern with the primordial religion manifested in Schuon's growing interest in Indigenous religion and spirituality, especially after reading John Neihardt's Black Elk Speaks (1932). He would later visit members of the Sioux tribe, and in 1959 would be adopted into the family of Chief James Red Cloud (1879-1960), leader of the Oglala Lakota on the Pine Ridge reservation in South Dakota (Fitzgerald 2010: 89). In the late 1940s, Guénon was getting reports from associates that Schuon was relaxing sharía requirements, allowing Christians to participate in Șúfi practices, and including themes for meditation from other traditions. Guénon saw this as a kind of "syncretism" that deviated from 
a genuinely Traditional approach, and encouraged his students to separate themselves from Schuon's 'Alawiyya, writing that Schuon was transforming the organisation into a "vague 'universalist' organisation" (Sedgwick 2004: 129).

During this period two associates of Guénon and Schuon's would go on to establish their own branches of Șüi orders, both with a more explicitly Guénonian orientation. Schuon had refused to admit a French associate of Guénon's, Roger Maridort (1903-1977), into the 'Alawiyya, as Maridort was living with a woman who was separated but still married to her husband. Guénon encouraged Maridort to go to Morocco, where he was initiated into the Darqawi branch of the Shadhili order, for which he would later receive an ijaza (authorisation) to establish his own group. With the majority of his followers in Italy, in 1961 Maridort relocated from France to Turin, establishing his branch of the Darqawiyya there. He further created the Rivista di Studitradizionali, an italian journal publishing translations of Guénon's works as well as works by Ṣuffi figures like Ibn al-Arabī. Maridorth's group would hold most closely to Guénon's Traditionalism, breaking markedly with Schuon and other Traditionalist Șūis (Sedgwick 2004: 131-133).

Michel Valsan (1907-1974) was a Romanian Traditionalist and diplomat who joined Schuon's 'Alawiyya, and helped establish a branch of the order in Bucharest in the 1930s. Beginning in 1940 Valsan led the Alawiyya in Paris, before separating from Schuon in 1951, after sharing Guénon's perspective that Schuon was taking the order in directions that deviated from Traditionalismproper. Valsan would then shift the Paris 'Alawiyya towards a more mainstream Islamic orientation. Valsan regularly attended Friday prayers in Paris and raised his family strictly in accord with the sharīa. His intellectual work was focused on publishing French translations of Ibn al-'Arabī's works. By his death in 1974 he had gathered around one hundred followers. Notable here is Michel Chodkiewicz (b. 1929), a convert to Islam who would also go on to publish respected translations and interpretations of Ibn al-Arabì (Chodkiewicz 1993a; Chodkiewicz 1993b). Chodkiewicz worked as a publisher and professor at the Sorbonne, earning some renown within French Islamic studies. Sedgwick credits Valsan and his followers with helping to establish Șüfism as a recognised and accessible expression of Islam in France (Sedgwick 2004: 133135). Unlike Guénon and Schuon, Valsan and Chodkiewicz were not beholden to Vedanta as the necessary barometer for authentic metaphysics, and more deeply enmeshed themselves in the study of the Șüfi-philosophical tradition, with their intensive focus on Muslim metaphysicians like Ibn al-'Arabī and his intellectual heirs.

Although he experienced periodic defections, Schuon's Maryamiyya would remain the most prominent Traditionalist organisation in the twentieth 
century. In 1965 Schuon had a vision of the Virgin Mary. Schuon understood the Virgin as an incarnation of both mercy and the perennial philosophy: his new relationship with her marked a turning point in his branch of the 'Alawiyya towards an even more universal orientation. For Schuon, the Virgin Mary represented the spiritual domain where different religions "lose much of their importance and where by way of compensation the essential elements they have in common are affirmed" (Lipton 2018: 136). Sedgwick summarises Schuon's spiritual lineage thus: "He was a Muslim with a Sufi initiation from the 'Alawiyya, appointed shaykh of a Sufi order in a vision, but he was also a universalist with a primordial initiation from the Sioux, appointed to a universal mission by the Virgin Mary in another vision" (Sedgwick 2004: 151). Although Schuon did not immediately change the name of his 'Alawiyya order following this vision, by the 1980 os the order was described by Schuon and his followers as the Maryamiyya, after the Virgin Mary.

In 1967 Victor Danner (1926-1990), a professor of religious studies in Bloomington, Indiana, established a Maryamiyya branch there. It would become the most important center of Schuon's order, and the site of the Maryamiyya's development toward a more universal orientation. Schuon moved to Bloomington in the Fall of 1980, establishing a community at Inverness Farms of about sixty or seventy Maryamiyyas. This new community at Bloomington focused more on Schuon's role as a primordial sage, at times somewhat critical of older Maryamiyyas more grounded in the outward practices of Islam (Dickson 2015: 115). Schuon wrote at this time, characterising this new phase of his life and teaching, that "the Holy Virgin is the living and heavenly link between Islam and Christianity, and that she also links us to Judaism and even to all religions" (Fitzgerald 2010: 119).

By the 198 os Schuon had also established himself as an author with a growing following. ${ }^{7}$ In many cases he proved able to elaborate upon Guenon's core ideas in ways that may have been more broadly accessible, at least to those with some philosophical inclination. His illustration of the perennialist perspective in his first book, De L'Unité transcendante des religions (1948) is exemplary in this regard:

7 Relevant works of Schuon's in English include The Transcendent Unity of Religions (1993 [1948], Understanding Islam (1998 [1963]), Sufism: Veil and Quintessence (2006 [1980]), and for some of Schuon's writings on Hinduism, Buddhism, and Indigenous traditions, see Language of the Self: Essays on the Perennial Philosophy (2003 [1959]). For a summary of Schuon's thought, see The Essential Frithjof Schuon, edited by Seyyed Hossein Nasr (2005). 
If an example may be drawn from the sensory sphere to illustrate the difference between metaphysical and theological knowledge, it may be said that the former, which can be called 'esoteric' when it is manifested through a religious symbolism, is conscious of the colorless essence of light and of its character of pure luminosity; a given religious belief, on the other hand, will assert that light is red and not green, whereas another belief will assert the opposite; both will be right insofar as they distinguish light from darkness but not insofar as they identify it with a particular color.

SCHUON 1993 [1948]: Xxx

Within the Maryamiyya, Indigenous traditions were incorporated into ritual practice and ritual dances that included sacred nudity were practiced by Schuon and his close students. Schuon himself articulated these practices in terms of the symbolism of nudity, representing the naked, esoteric truth that religious forms veil or cover. In an interview he affirmed that "In an altogether general way, nudity expresses - and virtually actualises-a return to the essence, the origin, the archetype, thus to the celestial state (Lipton 2018: 137). However, this symbolic practice eventually broke out into controversy when, in 1991, a disaffected former student of Schuon's brought charges against him of inappropriate contact with minors, involving ritual nudity. The charges were dropped due to insufficient evidence, though the controversey likely only increased the somewhat secretive nature of the group. Following Schuon's death in 1998, Seyyed Hossein Nasr would take over leadership of the largest branch of the Maryamiyya.

Nasr, a Professor of Islamic studies at George Washington University, is one of the most well-known North American scholars of Islam, having contributed to the development of the academic study of Islam, authoring over fifty books and around five hundred articles since he began publishing in the 1960s, and training several accomplished scholars of Islam (Chittick 2007: xiv). He is also the most influential living Traditionalist, playing an important role in articulating the Islamic legitimacy of Schuon and the Maryamiyya.

Nasr was born in 1933 to an elite Iranian family tied to the late shah, Reza Pahlavi (1919-1980), and with connections to Iranian Șūfi orders (Dickson 2015: 116). He pursued secondary and post-secondary studies in America and discovered Traditionalism during his time as an undergraduate in science at MIT, when he found himself in an intellectual crisis. Following a transformative encounter with Guénon's works, Nasr describes how he then discovered the writings of Guénon's associates Coomaraswamy and Schuon: 
That step led me to the writings of [Ananda] Coomaraswamy and Frithjof Schuon, and finally my meeting with Schuon in Europe and my going to North Africa. I became directly involved in the Shadhili order, emanating from Shaykh al-Alawi, an Algerian shaykh. I was only 24 years old, in Morocco and Europe. I have been associated with Sufism since then.

DICKSON 2O15: 117

Nasr first met Schuon in 1957 in Lausanne (2006 [1980]: viii). He became a member of Schuon's order and eventually established a branch of the Maryamiyya in Tehran. He was better known however for his Imperial Iranian Academy of Philosophy, which, during its time, was the most prominent educational institution based on Traditionalist principles. Established in 1974, Nasr's Academy hosted world-renowned scholars of Islam like Henry Corbin (1903-1978) and Toshihiko Izutsu (1914-1993), and trained William Chittick, who is now the foremost English-language scholar and translator of Ibn al-'Arabī (Chittick 1989, 1998). Nasr's connections with the Pahlavi regime made his place in Iran untenable after the revolution in 1979, and he left for America where he has lived since.

Following Schuon's death in 1998, Nasr would become the leader of the largest branch of the Maryamiyya. Due to his own Muslim background and scholarship, and perhaps to counter claims that the Maryamiyya are not authentically Șüfi or Muslim, Nasr has emphazied the order's Islamic nature, and affirmed Schuon's function as a Muslim Șūfi shaykh. In an article for the Traditionalist journal Sophia, "Frithjof Schuon and the Islamic Tradition" (1999), Nasr notes Schuon's role as a messenger of "universal and perennial wisdom," but maintains that "his function to speak of pure esoterism should not, however, detract anyone one moment from thinking that he is anything other than a Muslim in the deepest sense of the term and that he practiced the tenets of the Islamic tradition, on both the levels of the law and the way." Nasr further suggests that Schuon's integration of Christian and Indigenous elements into the spiritual life of the Maryamiyya "can be explained in the light of Sufism" (Nasr 1999: 30-31). Nasr's article reflects one of the two competing visions of Schuon's life and thought that have developed among Maryamiyyas. Whereas Nasr emphasises the Islamic nature of Schuon and his teachings, other students of Schuon have focused on his almost divine role as the messenger of pure esoterism beyond any single tradition.

In contrast to Schuon's notable criticism of Șūfism for its "Semitic" subjectivism and dogmatic moralism, Nasr's writings focus almost exclusively on the positive aspects of the Islamic tradition. This difference results from Schuon's strong prioritisation of the esoteric over the exoteric, a prioritisation 
that Nasr does not share to the same degree. For Schuon, the esoteric nucleus of a religion "is not in any sense a part, even an inner part, of the exoterism, but represents, on the contrary, a quasi-independent 'dimension' in relation to the latter" (Schuon 1993 [1948]: 9-10). This qualified distinction between a religion's esoteric and exoteric elements contrasts with Nasr's perspective on Șufism as the crystallisation of Islam's inner dimension, a perspective in which Islam's exoteric and esoteric elements are organically joined. Patrick Laude concisely notes this difference, suggesting that, "Seyyed Hossein Nasr's intellectual and spiritual path is different from Schuon's, since the latter starts from esoterism to go toward Islam while the former has its starting point is Islam while its ultimate destination is esoterism or gnosis" (Laude 2003).

Unlike Schuon, a European who embraced Islam as an expedient part of his search for esoteric knowledge, Nasr was born into a Muslim family in Iran, one deeply connected to the historic Islamic tradition there. With his scholarly career, Nasr has written on many of the varied facets of the Islamic tradition as a whole, ranging from philosophy, art, and spirituality, to law and theology. This depth of engagement with Islam's intellectuality is not paralleled by any other Traditionalist writer. Nasr's focus on the Islamic nature of Șufism and the Maryamiyya coincides with his lifelong association with and study of the Islamic tradition.

Non-Traditionalist Muslims have had various takes on the legitimacy of Traditionalism and the Maryamiyya. Hamza Yusuf, an American convert who has become one of the most prominent Muslim leaders in the West, and founder of Zaytuna College (the first accredited Muslim undergraduate college in America), was deeply influenced by Martin Lings' works. Yusuf met with him several times and had a great respect for his piety and scholarship. In his lengthy 2005 obituary for Lings, Yusuf suggests he and other Muslim authorities who knew him, including the well-known Yemeni scholar Habib 'Ali alJifri, felt that:

Dr. Lings was most certainly a devout and pious Muslim, fully committed to the teaching of the Prophet and one who rooted his thought and practice in the Quran despite our clear differences with him on the subject of perennialism. I believe that his spiritual presence was a cogent argument for his practice and commitment.

YUSUF 2005: 55

Both Yusuf and al-Jifri fall within a broader movement to revive the classical Sunnī synthesis of Islamic law ( figh), theology (kalām), and Șūfism (tașawwuf), what Jonathan Brown calls "late Sunni traditionalism" (Brown 2014: 29). Many 
of their concerns overlap with those of Traditionalists and so it is not necessarily surprising that there would be a great deal of sympathy between them despite their difference on the issue of perennialism. In contrast to Yusuf and al-Jifri's understanding of Traditionalism as something that deviates from mainstream Islamic theology, but not in a way that fundamentally compromises one's Muslim faith and practice, Nuh Ha Mim Keller, another American convert who is also a Șūfi leader and scholar of Islamic law, has condemned the belief in the universal validity of non-Islamic religions as kufr or unbelief (Keller 1996).

\section{Conclusion}

Emerging out of the occult milieu of fin de siècle Paris, Guénon inherited from his varied experience of esoteric movements a Vedanta-oriented perennialism alongside a concern for authentic initiation. In addition, Guénon developed a critique of modernity and valorised traditional religion as the carrier of the metaphysical truths of the Primordial Tradition. Guénon would further come to see Islam and its esoteric tradition, Șūism, as offering the most expedient means for Westerners to access this Primordial Tradition, which he believed the West had long ago lost connection to. As a sort of successor, Schuon then elaborated upon Guénonian themes in his prolific writings during the latter half of the twentieth century, and further became a Șüf shaykh in his own right, establishing the Maryamiyya as the predominant expression of Traditionalism in practice.

Although both Guénon and Schuon believed that adherence to a religion's exoteric morals and laws was a requirement to practice its esoteric path, and hence believed that genuine Șüfis should be committed Muslims, they tended to interpret Islamic thought through the lens of Hinduism's Advaita Vedanta philosophy, which continued for them to be the hallmark of explicit metaphysical truth. Schuon in particular criticised conventional Islamic theology and devotion as overly moralistic in nature, in some cases inhibiting the realisation of pure metaphysics, and was comfortable integrating Christian and Indigenous religious symbols and practices into his order. However, both Guénon and Schuon held Șüfism and its Islamic form to be one of the most accessible means of Traditional initiation, and their writings on Șufism and personal practice of Islam were paradigmatic for most Traditionalists who followed them, leading to the establishment of a Traditionalist Islam in Europe and North America. In his scholarship, Nasr would further ground Traditionalism within Islam, as would Burkhardt, Lings, 
Valsan, and Chodkiewicz in Europe. Taken as a whole, the body of literature on Islam and Șufism produced by Traditionalists, academic and otherwise, has had a profound influence on Western understandings of Islam, and led to its adoption as a spiritual path by several Western intellectuals, and countless others influenced by their work. Traditionalism then, forms an important element of Islam's establishment as an intellectual orientation and religious practice in Europe and North America.

\section{References}

Benoit, M. 2010. "The Intellectual Adventures of William Jones (II): "The Justinian of India." Revue de la Société d'études anglo-américaines des XVII ${ }^{e}$ et XVIII ${ }^{e}$ siècles. 67 , 187-202.

Brown, J. 2014. "Scripture in the modern Muslim world: Qur'an and Hadith," In J.T. Kennedy and E. Moosa eds, Islam in the Modern World. New York: Routledge.

Burckhardt, T. 1992. Fez: City of Islam. Cambridge: Islamic Texts Society.

Burckhardt, T.2008.Introduction to SufiDoctrine:Commemorative Edition. Bloomington, IN: World Wisdom.

Burckhardt, T. 2010. Chartres and the Birth of the Cathedral: Revised Edition. Bloomington, IN: World Wisdom.

Chittick, W.C. 1989. The Sufi Path of Knowledge: Ibn al-Arabìs Metaphysics of Imagination. Albany: State University of New York Press.

Chittick, W.C. 1998. The Self-Disclosure of God: Principles of Ibn al-Arabis Cosmology. Albany: State University of New York Press.

Chittick, W.C. 2004. "The Central Point: Qunawi's Role in the School of Ibn 'Arabì." Journal of the Muhyiddin Ibn 'Arabi Society. xxxv, 25-46.

Chittick, W.C. ed. 2007. The Essential Seyyed Hossein Nasr. Bloomington, IN: World Wisdom.

Chodkiewicz, M. 1993a. Seal of the Saints: Prophethood and Sainthood in the Doctrine of Ibn 'Arabī. Cambridge: Islamic Texts Society.

Chodkiewicz, M. 1993b. An Ocean Without Shore: Ibn Arabi, the Book, and the Law. Albany: State University of New York Press.

Chodkiewicz, M. 1995. The Spiritual Writings of Amir 'Abd al-Kader. Albany: State University of New York Press.

Dickson, W.R. 2015. Living Sufism in North America. Between Tradition and Transformation. New York: State University of New York Press.

Doniger, W. 20og. The Hindus: An Alternative History. New York: The Penguin Press.

Fitzgerald, O. 2010. Frithjof Schuon:Messenger of the Perennial Philosophy. Bloomington: World Wisdom. 
Franklin, M.J. 2011. Orientalist Jones: Sir William Jones, Poet, Lawyer, and Linguist 17461794. New York: Oxford University Press.

Guénon, R. 2001 [1925]. Man and His Becoming according to the Vedanta. Ghent, NY: Sophia Perennis.

Guénon, R. 2004 [1927]. The Crisis of the Modern World. Hillsdale, NY: Sophia Perennis. Guénon, R. 2004 [1945]. The Reign of Quantity and the Signs of the Times. Hillsdale, NY: Sophia Perennis.

Guénon, R. 2004 [1952]. Initiation and Spiritual Realization. Hillsdale, NY: Sophia Perennis.

Hallaq, W.B. 2018. Restating Orientalism: A Critique of Modern Knowledge. New York: Columbia University Press.

Keller, N.H.M. 1996. "On the validity of all religions in the thought of ibn Al-'Arabī and Emir 'Abd al-Qadir: a letter to 'Abd al-Matin." Masud.co.uk. At http://masud.co.uk/ on-the-validity-of-all-religions-in-the-thought-of-ibn-al-arabi-and-emir-abd-al -qadir-a-letter-to-abd-al-matin/. Accessed 25/05/2020.

Laude, P. 2003. "Seyyed Hossein Nasr in the Context of the Perennialist School." In M.H. Faghfoory ed., Beacon of Knowledge: Essays in Honour of Seyyed Hossein Nasr. Louisville, KY: Fons Vitae, 245-26o.

Laude, P. 2010. Pathways to an Inner Islam: Massignon, Corbin, Guénon, and Schuon. Albany, NY: State University of New York Press.

Lings, M. 1993. A Sufi Saint of the Twentieth Century: Shaikh Ahmad al-'Alawi. Cambridge: Islamic Texts Society.

Lings, M. 20o6. Muhammad: His Life Based on the Earliest Sources, fifth edition. Rochester, VT: Inner Traditions.

Lipton, G.A. 2018. Rethinking Ibn Arabī. New York: Oxford University Press.

Lowrie, J.O. 1985. "René Guénon and the Esoteric Thought of Andre Pieyre de Mandiargues." The French Review. 58, 392.

Masuzawa, T. 2005. The Invention of World Religions, or How European Universalism was Preserved in the Language of Pluralism. Chicago: University of Chicago Press.

Nasr, S.H. 1999. "Frithjof Schuon and the Islamic Tradition." Sophia. 5, 30-31.

Nasr, S.H. ed. 2005. The Essential Frithjof Schuon. Bloomington, IN: World Wisdom.

Oldmeadow, H. 1995. “Introduction.” In R. Guénon, The Reign of Quantity and the Signs of the Times. Ghent, NY: Sophia Perennis.

Rawlinson, A. 1997. The Book of Enlightened Masters: Western Teachers in Eastern Traditions. Chicago: Open Court.

Said, E. 1978. Orientalism. New York: Pantheon Books.

Schmitt, C.B. 1966. "Perennial Philosophy: From Agostino Steuco to Leibniz." Journal of the History of Ideas. 27:4, 505-532.

Schuon, F. 1993 [1948]. The Transcendent Unity of Religions. Wheaton, IL: Quest Books. 
Schuon, F. 2003 [1959]. Language of the Self: Essays on the Perennial Philosophy. Bloomington, IN: World Wisdom.

Schuon, F. 2004 [1984]. René Guénon: Some Observations. Hillsdale, NY: Sophia Perennis.

Schuon, F. 2006 [1980]. Sufism: Veil and Quintessence. Bloomington, IN:World Wisdom.

Sedgwick, M. 2004. Against the Modern World: Traditionalism and the Secret Intellectual History of the Twentieth Century. Oxford: Oxford University Press.

Sedgwick, M. 2008. "Foreword." In Graham Rooth ed., Prophet for a Dark Age: A Companion to the Works of René Guénon. Portland: Sussex Academic Press, i-xxix.

Sedgwick,M.2011. “GuénonianTraditionalismand EuropeanIslam.” InM.vanBruinessen and S. Alleivi eds, Producing Islamic Knowledge: Transmission and Dissemination in Western Europe. Abingdon: Routledge, 169-187.

Sedgwick, M. 2017. Western Sufism: Form the Abbasids to the New Age. Oxford: Oxford University Press.

Sedgwick, M. 2019. “Remarkable new book draws on Guénon.” Traditionalists: A Blog for the study of Traditionalism and Traditionalists. At https://raditionalistblog.blogspot .com/2019/o3/remarkable-new-book-draws-on-guenon.html. Accessed 23/05/2020.

Waterfield, R. 2002. René Guénon and the Future of the West. Hillsdale, NY: Sophia Perennis.

Yusuf, H. 2005. "A Spiritual Giant in an Age of Dwarfed Terrestial Aspirations." Q-News. $363,53-58$. 